\title{
REKONTRUKSI PERJ ANJ IAN GALA (GADAI ADAT) PADA MASYARAKAT ADAT ACEH BERBASIS SYARIAH
}

\author{
Muhammad lqbal*, Sukirno** \\ PROGRAM STUDI MAGISTER ILMU HUKIUM \\ FAKULTAS HUKUM UNIVERSITAS DIPONEGORO \\ kirnoundip@yahoo.com
}

\begin{abstract}
ABSTRAK
Gala merupakan suatu perjanjian pinjam-meminjam antara pihak pemberi gala dan penerima gala dengan konsep tolong-menolong pada untuk memenuhi kebutuhan keuangan dalam keadaan yang bersifat mendesak. Jika melihat pelaksanaan perjanjian gala dalam masyarakat adat Aceh pada saat ini adanya ketidak sesuaian antara pelaksanaan dan aturan pada Pasal 2 (dua) ayat (2) Qanun Nomor 9 Tahun 2008 tentang Adat dan Istiadat serta ketentuan Pasal 7 Perpu Nomor 56 Tahun 1960 tentang Penetapan Luas Tanah Pertanian. Rumusan masalah pada tesis ini adalah bagaimanakah bentuk pelaksanaan perjanjian gala dalam masyarakat adat Aceh? bagaimanakah kaitan antara perjanjian gala dengan konsep gadai syariah? bagaimanakah bentuk rekonstruksi perjanjian gala berbasis syariah? Metode penelitian yang digunakan adalah pendekatan yuridis empiris dan pendekatan socio-legal. Selain data sekunder, juga digunakan data primer dari serangkaian observasi dan wawancara dengan informan. Perjanjian gala dilakukan jika pemberi gala membutuhkan uang yang banyak dalam keadaan mendesak. Dalam mekanisme perjanjian gala, para pihak yang telah sepakat untuk melaksanakan perjanjian gala melakukan penyerahan objek gala dari pihak pemberi gala kepada pihak penerima gala dalam bentuk hak pakai, sedangkan dipihak penerima gala menyerahkan sejumlah uang yang telah disepakati antara keduanya secara tunai. Berakhirnya suatu perjanjian gala dalam masyarakat adat Aceh ketika objek gala tersebut telah ditebus. Jika dikaitkan perjanjian gala di Aceh dengan konsep gadai syariah maka adanya ketidak sesuaian terhadap pemanfaatan dan penguasaan dalam konsep gadai syariah. Sebagian besar para ulama tidak membolehkan pemanfatan objek gala dengan tidak adanya suatu batasan waktu. Pemanfatan objek gala dibolehkan jika para pihak sepakat untuk menerapkan tiga akad perjanjian Perjanjian gala dengan bentuk Al-Qardhul Hassan, Al-Mudharabah dan Bai' Al-Muqoyyadah agar tehindar dari unsur gharar dan riba. Salah satu bentuk rekontruksi pada perjanjian gala yang berbasis syariah dengan menerapankan konsep mudharabah hasil keuntungan yang diperoleh dari objek gala oleh penerima gala digunakan untuk menutup kembali utang pihak pemberi gala. Pemerintah Aceh diharapkan agar membuat qanun khusus tentang tata cara dan tatacara pelaksanaan gala yang sesuai dengan ketentuan Islam dan berbasis syariah. Sehingga pelaksanaan adat di Aceh tidak melanggar ketentuan islam.
\end{abstract}

\section{Kata Kunci: Berbasis Syariah; Masyarakat Adat Aceh; Perjanjian Gala}

\footnotetext{
* Mahasiswa Program Studi Magister IImu Hukum UNDIP

${ }^{*}$ Penulis Kedua, Penulis Koresponden
} 


\section{Pendahuluan}

\section{A. Latar Belakang}

Masyarakat adat Aceh dalam tatanan sosial masih menjunjung tinggi dan menjaga nilai-nilai adat-istiadat dalam kehidupan sehari-hari. Salah satu bentuk adat yang masih digunakan dalam kehidupan masyarakat adat Aceh sampai saat ini adalah gala (gadai adat). Adat Gala dalam masyarakat adat Aceh mempunyai nilai-nilai dan konsep kebersamaan dan tolong-menolong antar sesama manusia (habluminannas) dan mengharapkan ridha (pahala) dari Allah (wa habluminallah). ${ }^{1}$

Gala merupakan suatu perjanjian pinjammeminjam antara pihak pemberi gala dan pihak penerima gala untuk memenuhi kebutuhan keuangan dalam keadaan mendesak dalam kehidupan sehari-hari. Dalam mekanisme perjanjian gala jika para pihak telah sepakat untuk melakukan perjanjian gala, maka pihak pemberi gala menyerakan hak pakai atas objek gala sebagai benda jaminan kepada pihak penerima gala, sedangkan pada pihak penerima gala menyerahkan uang sebesar yang diperjanjikan antara kedua belah pihak tersebut secara tunai kepada pihak pemberi gala.

Dalam sistem Gala, penggala (pemilik harta) memberikan hak pakai kepada penerima

\footnotetext{
1 Taqwaddin Husen, Kapita Selekta Hukum Adat Aceh dan Qanun Wali Nanggroe, Bandar Publishing, Banda Aceh, 2013, hal. 90
}

gala untuk menggunakan harta galaan yang dijadikan agunan selama pemberi gala belum menebus objek gala. Hasil yang diperoleh penerima gala atas penggunaan objek gala tersebut dianggap sebagai balas jasa atas uang yang dipinjamkan.2 Jika diperhatikan mekanisme pelaksanaan perjanjian gala di dalam kehidupan masyarakat adat Aceh, berakhirnya suatu perjanjian gala adalah tanpa adanya suatu ketetapan batas waktu selain objek gala ditebus tentunya akan memberatkan pihak pemberi gala dikarenakan objek gala (agunan) yang dulunya digunakan sebagai alat yang digunakan untuk mencari nafkah untuk menebus harta gala tersebut telah beralih menjadi hak pakai kepada pihak penerima gala. Sedangkan disisi yang lain, pihak penerima gala terus menikmati hasil dari objek gala (agunan) tersebut tanpa mengurangi jumlah utang pihak pemberi gala.

Dalam konteks ekonomi Islam objek gadai (agunan) digunakan sekadar untuk memastikan (jaminan) kepercayaan pada pihak pemberi gadai. Dalam Islam tidak membenarkan adanya pemanfaatan terhadap objek gala jika menimbulkan kemudharatan kepada pemberi gadai. Sebagian besar ulama hanya berpendapat Pemanfaatan dibolehkan sebesar pengeluaran pihak penerima gadai terhadap barang gadaian, misalkan pihak

2 Azharsyah Ibrahim, Praktik Ekonomi Masyarakat Aceh dalam Konteks Ekonomi Islam, Malaysia, Procceeding of the Aceh development International Conference, International Islamic University, 2012, hal. 445. 
penerima gadai boleh menikmati susu sapi gadaian sebanyak makanan yang diberikan untuk lembu. ${ }^{3}$ Ketidak sesuaian pelaksanaan perjanjian gala dengan ketentuan syariah tentunya akan bertentangan dengan ketentuan Pasal 2 ayat (2) Qanun Nomor 9 Tahun 2008 tentang Adat dan Istiadat menyebutkan pembinaan, pengembangan, pelestarian dan perlindungan terhadap adat dan istiadat harus meliputi dan berpedoman pada nilainilai Islami. Dan tidak adanya batasan waktu akan bertentangan dengan Undang-Undang Nomor 56/Prp/Tahun 1960 tentang Penetapan Luas Tanah Pertanian yang menyatakan bahwa gadai tanah tidak boleh lebih 7 tahun.

Maka melihat permasalahan tesebut penulis tertarik untuk melakukan penelitian dengan judul: "Rekonstruksi Perjanjian Gala (Gadai Adat) pada masyarakat adat Aceh berbasis syariah".

B. Rumusan Permasalahan

Berdasarkan latar belakang di atas, maka terdapat beberapa rumusan permasalahan sebagai berikut:

1. Bagaimanakah bentuk pelaksanaan perjanjian gala dalam masyarakat adat Aceh?

2. Bagaimanakah kaitan antara perjanjian gala dengan konsep gadai syariah?

3. Bagaimanakah bentuk rekonstruksi perjanjian gala berbasis syariah?

3 A. Ghofur Anshori, Gadai Syariah di Indonesia, Gadjah Mada University Press, Yogyakarta, 2006, hal. 117.

\section{Metode Penelitian}

A. Jenis Penelitian

Berdasarkan perumusan masalah serta tujuan maka pendekatan digunakan merupakan pendekatan yuridis empiris. Pendekatan ini digunakan dalam rangka menemukan bentuk perjanjian gala yang hidup dalam pada masyarakat adat Aceh berdasarkan perspektif syariah. Pendekatan ini tidak berhenti pada hukum dalam ketentuan perundang-undangan, namun melihat hukum dalam konsepsi hukum yang hidup dalam masyarakat. ${ }^{4}$

B. Jenis Data

Dalam mencari dan mengumpulkan data yang diperlukan yang difokuskan berdasarkan pokok permasalahan yang ada, sehingga dalam penelitian ini tidak terjadinya penyimpangan dan kekaburan dalam pembahasan. Adapun data yang akan digunakan dalam penelitian ini adalah sebagai berikut:

1. Data Primer

Data primer yang digunakan diperoleh dari penelitian lapangan (field research). Data lapangan dibutuhkan untuk memperoleh informasi mengenai eksistensi, mekanisme serta penyelesaian sengketa dalam perjanjian gala dalam kehidupan masyarakat adat di Aceh, melalui informan dan observasi.

4 Soetandyo Wignjosoebroto, Hukum: Paradigma.Metode dan Dinamika Masalahnya, HuMa, Jakarta, 2012, hal. 160. 


\section{Data Sekunder}

Data sekunder diperoleh melalui hasil penelitian kepustakaan (library research), berupa bahan hukum primer (peraturan perundang-undangan), bahan hukum sekunder (jurnal-jurnal dan hasil penelitian ilmiah lainnya).

\section{Data Tersier}

Data tersier adalah bahan hukum yang merupakan bahan-bahan yang memberikan informasi-informasi tentang bahan-bahan hukum primer dan sekunder antara lain kamus-kamus, ensiklopedia, artikel-artikel, majalah, Koran, dan dokumen-dokumen yang berkaitan dengan perjanjian gala.

C. Spesifikasi Penelitian

Spesifikasi pada penelitian ini ialah Sociolegal research, dilakukan dengan cara menggabungkan pengetahuan, keahlian, dan pengalaman dari dua atau beberapa disiplin (interdisipliner) untuk menjawab suatu persoalan hukum. dalam hal ini, masalah hukum diselesaikan dengan menggabungkan kajian hukum dan sosiologis-antropologis, khususnya pluralism hukum. ${ }^{5}$

5 Reza Banakar and Max Travers, "law Sociology and Method", in Social and Legal Studies, International Institute, 2003, p. 4-5. Menurut Esmi Warassih, konsep hukum dimaknai sebagai manifestasi makna-makna simbolik para pelaku sosial sebagaimana tampak dalam interaksi mereka. Lihat, Esmi Warassih, "Urgensi Memahami Hukum dengan Pendekatan Socio-Legal dan Peranannya dalam Penelitian". Makalah Seminar Nasional Penelitian dalam Perspektif Socio-
D. Metode Analisis Data dan Validasi Data

Metode Analisis data yang digunakan dalam penelitian ini adalah metode analisis data kualitatif. Analisis data kualitatif adalah suatu cara penelitian yang menghasilkan data analitis, yaitu yang dinyatakan oleh responden secara tertulis atau lisan dan juga perilakunya yang diteliti dan dipelajari sebagai sesuatu yang utuh.

Pada validasi data menggunakan teknik triagulasi sumber (menggunakan komparasi data dan sumbernya untuk mensistematisasi perbedaan dan persamaan pandangan berdasarkan kualifikasi dan situasi sumber dengan dokumen) dan metode (pengecekan melalui teknik pengumpulan data, observasi partisipatif, dan wawancara mendalam).

\section{Pembahasan}

A. Bentuk Pelaksanaan Perjanjian Gala dalam Masyarakat Adat Aceh

Legal dan, Bagian Hukum dan Masyarakat Fakultas Hukum Undip, Semarang, 22 Desember 2008, hal. 6. Tujuan SocioLegal Research sendiri merupakan suatu pemahan hukum secara lebih menyeluruh. Model penelitian ini, terutama untuk hal-hal yang tidak terjangkau oleh ancangan normatif. Lihat Satjipto Rahardjo, Pendidikan Hukum sebagai Pendidikan Manusia: kaitannya dengan profesi Hukum dan Pembangunan Hukum Nasional, Genta Publishing, Yogyakarta, 2009, hal. 43. Kajian ini juga melihat hukum dalam konteks masyarakat. Satjipto Rahardjo, LapisanLapisan dalam Studi Hukum, Bayumedia Publishing, Malang, 2009, hal. 127. Brian Z. Tamanaha, A General J urisprudence of Law and Society, Oxford University Press, New York, 2006, p. 2. 
Gala merupakan perjanjian pinjam- maka hasil kesepakatan yang telah disepakati meminjam uang atau emas dengan menjadikan dituangkan dalam surat perjanjian gala pada tanah atau barang-barang lainnya yang dianggap berharga sebagai objek jaminan (agunan). Perjanjian gala kurang lebih telah berada dan hidup dalam masyarakat adat Aceh sejak abad ke 17 (tujuh belas) dan masih berlangsung sampai dengan sekarang. Pada awal-awal perkembangannya perjanjian gala dalam masyarakat adat Aceh tempo dulu biasanya dilakukan secara lisan atau tidak tertulis, dengan anggapan bahwa apa yang diperjanjikan oleh kedua belah pihak tersebut telah disepakat dan kedua belah pihak di anggap telah memahami tentang apa saja yang menjadi hak dan kewajiban diantara mereka, sehingga dengan berlandaskan saling percaya antara sesama inilah menjadi suatu ciri khas dalam perjanjian gala menurut hukum adat di Aceh. ${ }^{6}$

Seiring berjalannya waktu perjanjian gala terus berkembang sehingga perkembangannya perjanjian gala dipengaruhi oleh budaya luar akibat kemajuan teknologi dan perubahan alur pikir masyarakat. Pengaruh tersebut membawa perubahan bersifat positif dan negatif kepada beberapa kegiatan masyarakat dalam bidang ekonomi.

Dalam pelaksanaanya jika para pihak telah sepakat antar untuk melakukan perjanjian gala,

${ }^{6}$ Badruzzaman Ismail, Ketua Majalis Adat Aceh, Wawancara, 21 Desember 2016. umumnya hanya memuat judul (keterangan surat), pembukaan, identitas serta alamat dari pihak pemberi gala (urueng peugala) dan pihak penerima gala (urueng teurimong gala), letak objek yang digalakan, keterangan dari barang agunan dan penutup yang disertai dengan tanda tangan dari pihak pemberi gala (urueng peugala) dan pihak penerima gala (urueng teurimong gala) yang melakukan perjanjian gala, diikuti dengan tanda tangan dari saksi dan keuchik gampong setempat, dan selanjutnya diikuti dengan serah terima (ijab Kabul) dari kedua belah pihak di mana pihak pemberi gala (urueng peugala) menyerahkan tanahnya atau objek jaminan sebagai jaminan gala (barang agunan) kepada pihak penerima gala (urueng trimong gala) dalam bentuk hak pakai, sedangkan dipihak penerima gala (urueng trimong gala) menyerahkan uang dengan kesepakatan yang dipenuhi sebagaimana telah diperjanjikan antara keduanya dalam bentuk tunai.

Pada pelaksanaan perjanjian gala, pemilik harta atau disebut dengan pemberi gala (urueng peugala) menyerahkan hak pakai dan penguasaan atas objek gala (benda agunan) kepada orang yang memberi pinjaman atau biasa disebut penerima gala (urueng teurimong gala) untuk menggunakan harta galaan sebagai objek gala (agunan) selama pemilik belum menebusnya. 
Jurnal Law Reform

Volume 13, Nomor 1, Tahun 2017

Berakhirnya suatu perjanjian gala dalam masyarakat adat Aceh adalah ketika objek gala (barang agunan) tersebut telah ditebus, dalam hukum adat Aceh adanya pepatah yang mengatakan "Iheuh ngui payah ta pulang, miseu utang payah ta bayeu, akhe dari janji gala ngon teuboh". Yang artinya suatu perjanjian pinjammeminjam baru dianggap berakhir apabila barang yang yang dipinjam tersebut telah dikembalikan, begitu juga dengan perjanjian utang baru akan dianggap telah berakhir apabila telah dibayar dan perjanjian gala baru dianggap selesai (berakhir) apabila objek gala (barang agunan) telah ditebus.

Selama berlangsungnya perjanjian gala barang jamiman berada dalam penguasaan penerima gala (urueng teurimong gala) maka selama objek gala (barang agunan) belum ditebus oleh pihak pemberi gala (urueng peugala) maka pihak penerima gala (urueng teurimong gala) berhak untuk menikmati hasil dari objek gala (barang agunan) dikarenakan pemanfaatan atas objek gala merupakan suatu bentuk balas jasa dari pihak pemberi gala (urueng peugala) atas uang atau emas yang dipinjamkan oleh pihak penerima gala (ueureng teurimong gala). Maka berdasarkan adanya anggapan suatu bentuk balas jasa oleh karena itulah di dalam surat perjanjian gala tidak menyebutkan klausula batas waktu penebusan. ${ }^{7}$

7 Armia, Ketua Majelis Adat Aceh Kabupaten Pidie Jaya, Wawancara, 9 Januari 2017.
Program Studi Magister Ilmu Hukum Fakultas Hukum Universitas Diponegoro

B. Kaitan Antara Perjanjian Gala dengan Gadai Syariah

1. Konsep perjanjian gala dan gadai syariah.

Gadai Syariah sering diidentikkan dengan rahn secara definisi rahn menurut istilah yaitu menjadikan suatu benda yang mempunyai nilai harta dalam pandangan syara' untuk kepercayaan suatu utang, sehingga memungkinkan mengambil seluruh atau sebahagian utang dari benda itu. Para ulama telah menyepakati bahwa perjanjian gala (rahn) hukumnya boleh dan tidak wajib karena pada sifat dari objek gadai (barang agunan) hanya merupakan jaminan saja jika kedua belah pihak tidak saling mempercayai. Akan tetapi, jika kedua belah pihak saling mempercayai satu sama lain, maka jaminan mungkin tidak diperlukan. Hal ini tercermin dari firman Allah berikut: "Jika sebagian kamu mempercayai sebagian yang lain, hendaklah yang dipercaya itu menunaikan amanatnya (utangnya)" (QS. Al-Baqarah: 283). Ayat ini juga memberikan tafsiran bahwasanya jaminan hanya disyaratkan jika tidak ada penulis di antara orang yang bertransaksi tersebut.

Perjanjian gala yang berada dalam masyarakat adat Aceh merupakan suatu perjanjian pinjam-meminjam yang dapat dipersamakan dengan suatu perjanjian gadai yang dianggap sebagai suatu perbuatan yang berlandaskan nilainilai ta'awun (tolong-menolong) antar sesama manusia. Konsep tolong-menolong juga didasari 
pada konsep kebersamaan bagi masyarakat adat Aceh adanya suatu anggapan membantu antar sesama yang menjadi sebuah perbuatan yang sangat mulia selain dimata Allah dan juga dimata manusia. ${ }^{8}$

\section{Batasan waktu dan penguasaan objek gala ditinjau dari aspek perekonomian islam.}

Pada suatu sistem perekonomian di dalam Islam terdapat beberapa landasan yang menjadi konsep dasar sebagaimana berikut:

1) Pelarangan akan adanya suatu ketidakpastian atau gharar.

2) Adanya pelarangan riba.

3) Pelarangan judi maisir.

4) Pelarang adanya suatu penipuan/tadlis.

5) Pelarangan terhadap perdangangan yang tidak halal atau bernajis.

6) Penggunaan prinsip bagi hasil.

Perjanjian gala digolongkan dalam suatu perbuatan tabbaru' artinya perjanjian gala merupakan salah satu perjanjian di dalam transaksinya tidak ditujukan untuk memperoleh laba (transaksi nirlaba) dengan anggapan murni karena timbulkan atas dasar niat saling bantu-membantu antar sesama. ${ }^{9}$ Terbitnya Perpu Nomor 56 Tahun 1960 tentang Penetapan Luas Tanah Pertanian

8 Faisal Ali, Wakil Ketua Majelis Permusyawaratan Ulama Aceh, Wawancara, 21 Desember 2016.

9 Faisal Ali, Wakil Ketua Majelis Permusyawaratan Ulama Aceh, Wawancara, 21 Desember 2016. yang mengatur tentang batasan waktu gadai yang berobjekkan tanah pada alasannya tidak berlaku sebagai suatu patokan atas perjanjian gala namun dalam pelaksanaannya peraturan tersebut tidak dapat dijadikan patokan batasan dalam perjanjian gala dikarenakan sebagian masyarakat beralasan tidak tahu akan keberadaan aturan tersebut sehingga peraturan gala di aceh baru dianggap selesai jika telah dilakukan penebusan terhadap objek gala.

Berdasarkan bentuk pelaksanaan perjanjian gala yang tanpa adanya waktu yang tentunya dapat memberikan dampak-dampak perampasan (penindasan) bagi para pihak pemberi gala. Dalam konsep dasar sistem perekonomian Islam melarang adanya unsur ketidak pastian waktu atau gharar. ${ }^{10}$ Syaikhul Islam Ibnu Taimiyyah menyatakan, algharar adalah yang tidak jelas hasilnya. Sedangkan menurut Syaikh As-Sa'di, al-gharar adalah almukhatharah (pertaruhan) dan al-jahalah (ketidak jelasan). Perihal ini masuk dalam kategori perjudian. ${ }^{11}$ Adapun kaitan gharar dalam suatu perjanjian gala yang berkembang dalam kehidupan masyarakat adat Aceh yaitu tidak adanya batasan waktu berakhirnya perjanjian gala. Dalam syari'at Islam, jual beli gharar ini terlarang dikarenakan

10 Purbayu Budi Santosa, Larangan J ual Beli Gharar: Tela'ah Terhadap Hadis dari Musnad Ahmad Bin Hanbal, Universitas Diponegoro, Vol. 3, No. 1, Juni 2015, Hal 159.

11 Abdurrahman bin Nashir As-Sa'di, Tahqiq Asyraf Abdulmaqshud, Bahjah Qulub Al-Abrar wa Qurratu Uyuuni AlAkhyaar Fi Syarhi J awaami Al-Akhbaar, Cet. II, Th 1992M, Dar Al-Jail. hal 164. 
sistem jual beli gharar ini terdapat unsur memakan harta orang lain dengan cara batil.

- Di dalam Surat Al-Baqarah ayat 188 yang artinya:

"Dan janganlah sebagian kamu memakan harta sebahagian yang lain di antara kamu dengan jalan yang batil dan (janganlah) kamu membawa (urusan) harta itu kepada hakim, supaya kamu dapat memakan sebahagian daripada harta benda orang lain itu dengan (jalan berbuat) dosa, padahal kamu mengetahui".

- $\quad$ Di dalam Surat An-Nisa ayat 29 yang artinya: "Hai orang-orang yang beriman, janganlah kamu saling memakan harta sesamamu dengan jalan yang batil, kecuali dengan jalan perniagaan yang berlaku dengan suka sama suka di antara kamu. Dan janganlah kamu membunuh dirimu, sesungguhnya Allah adalah Maha Penyayang kepadamu".

- Dari Abu Hurairah, dari Nabi Muhammad SAW, beliau bersabda:

"Rasullah SAW melarang jual beli al-hashah dan jual beli gharar".

Larangan gharar dalam konsep perekonomi Islam bertujuan agar nantinya tidak adanya unsur ketidak pastian yang nantinya akan berdampak menimbulkan persengketaan antara pihak pemberi gala (urueng peugala) dengan pihak penerima gala (urueng teurimong gala). Pada suatu kontek dasar ekonomi Islam benda gala (agunan) hanya dapat dijadikan sebagai suatu objek jaminan atas kepercayaan pihak pemberi gala (urueng peugala) untuk menebus kembali kepada pihak penerima gala (urueng teurimong gala) sehingga dengan alasan tersebut pihak penerima gala (urueng teurimong gala) tidak ragu memberikan uang atau emas untuk pihak pemberi gala (urueng teurimong gala) dikeranakan adanya barang jaminan. Akan tetapi apabila para pihak sudah saling mempercayai maka perjanjian gala juga akan dibolehkan tanpa adanya agunan.

Pemanfaatan dan penguasaan dalam perjanjian gala atas pemanfaatan objek gala (barang agunan) oleh pihak penerima gala (urueng teurimong gala) dengan anggapan untuk mendapatkan untung, bunga dan hal lain yang tidak dibolehkan sesuai dengan konsep perekonomian Islam dikarenakan apabila adanya prinsip mencari keuntungan itu dapat menjurus ke riba. ${ }^{12}$ Islam mengajarkan pada umatnya untuk menjunjung tinggi nilai-nilai kemaslahatan ummah (kepentingan umum) yang apabila dikerjakan akan berdampak akan membawa manfaat dan meninggalkan perbuatan yang bersifat mudharat.

Pemanfataan dan penguasaan atas dasar kemaslahatan dengan tujuan saling bantumembantu antar sesama tentunya dibolehkan

12 Faisal Ali, Wakil Ketua Majelis Permusyawaratan Ulama Aceh, Wawancara, 21 Desember 2016. 
Jurnal Law Reform

Volume 13, Nomor 1, Tahun 2017

apabila pihak pemberi gala (urueng peugala) dan penerima gala (urueng teurimong gala) dalam pelaksanaan perjanjian gala sepakat untuk menerapkan 3 (tiga) akad perjanjian, antara lain adalah:

1) Perjanjian hutang piutang dengan gala dalam bentuk Al-Q ardhul Hassan.

Akad ini biasanya dilakukan pada nasabah yang ingin menggadaikan barangnya untuk tujuan konsumtif, maka untuk itu pemberi gala (urueng peugala) dikenakan biaya berupa upah atau biaya kepada pihak penerima gala (urueng teurimong gala) karena telah menjaga dan merawat objek gala (barang agunan).

2) Perjanjian hutang piutang dengan gala dalam bentuk Al-Mudharabah.

Akad mudharabah adalah akad yang dilakukan oleh pemberi gala (urueng peugala) yang menggalakan objek gala (barang agunan) untuk menambah modal usaha atau pembiayaan yang bersifat produktif. Dengan akad ini pemberi gala (urueng peugala) akan memberikan bagi hasil berdasarkan keuntungan yang didapat oleh pihak pemberi gala (urueng peugala) kepada penerima gala (urueng teurimong gala) sesuai dengan kesepakatan, sampai modal yang dipinjam dilunasi.

3) Perjanjian hutang piutang dengan gadai dalam bentuk Bai' Al-Muqoyyadah.
Program Studi Magister Ilmu Hukum Fakultas Hukum Universitas Diponegoro

Akad ba'i muqayyadah adalah akad yang dilakukan apabila pemberi gala (urueng peugala) ingin menggadaikan barangnya untuk keperluan yang bersifat produktif seperti pembelian peralatan untuk modal kerja. Untuk memperoleh pinjaman pemberi gala (urueng peugala) harus menyerahkan barang sebagai jaminan berupa barang-barang yang dapat dimanfaatkan, baik oleh rahin maupun murtahin. Dalam hal ini pemberi gala (urueng peugala) dapat memberi keuntungan berupa penetapan harga atas barang yang dibelikan oleh penerima gala (urueng teurimong gala).

\section{Bentuk Rekonstruksi Perjanjian Gala Berbasis Syariah}

Berakhirnya suatu perjanjian gala pada masyarakat adat Aceh adalah setelah pihak pemberi gala (urueng peugala) menebus harta galaanya pada pihak penerima gala (urueng teurimong gala). Berdasarkan kesimpulan tersebut dapat dikatakan bahwa perjanjian gala yang berada di dalam masyarakat adat Aceh itu tidak mempunyai batas waktu tertentu, akan tetapi berakhirnya gala adalah ketika telah ditebusnya objek gala (agunan).

Berdasarkan pendapat Ulama pemanfaatan dan pemanfaatan barang gala itu tidak dibolehkan apabila tidak mengurangi utang pihak pemberi gala (urueng peugala). Akan tetapi apabila dapat 
mengurangi hutang pihak pemberi gala (urueng peugala) dibolehkan apabila memenuhi persyaratan-persyaratan tertentu. Agar sahnya dan tepenuhinya persyaratan sahnya pemanfaantan terhadap objek gala maka para pihak pemberi gala (urueng peugala) dan pihak penerima gala (urueng teurimong gala) haruslah sepakat untuk membuat akad mudharabah. ${ }^{13}$

Konsep Penerapan Akad Mudharabah Dalam Perjanjian Gala.

Menurut sebagian besar Ulama mudharabah adalah suatu akad (perjanjian) kerjasama antara pihak penerima gala (urueng peugala) atau pemodal dan pemberi gala (urueng peugala) atau pengelola yang kemudian keuntungan dari kerjasama tersebut akan dibagi menurut kesepakatan kedua belah pihak. ${ }^{14}$ Penerapan akad mudharabah dalam perjanjian gala dibolehkan karena bertujuan untuk membantu-membantu (tolong-menolong) pihak yang membutuhkan uang dalam hal ini adalah pihak pemberi gala (urueng peugala) dengan pihak yang mempunyai modal atau pihak penerima gala (urueng teurimong gala). ${ }^{15}$

Mekanisme penerapan akad mudharabah dalam perjanjian gala dilakukan setelah adanya

\footnotetext{
13 Faisal ali, wakil ketua majelis permusyawaratan Ulama, Wawancara, 21 Desember 2016.

14 Muhammad, Tehnik Perhitungan Bagi Hasil di Bank Syariah, UII Press, Yogyakarta, 2001, hal 47.

${ }_{15}$ Faisal Ali, Wakil Ketua Majelis Permusyawaratan Ulama Aceh, Wawancara, 21 Desember 2016.
}

kesepakatan dari para pihak dalam perjanjian gala yang disertai bentuk serah terima antara keduanya, di mana pihak pemberi gala (urueng peugala) menyerahkan objek galaanya kepada pihak pemberi gala (urueng peugala) dan disisi lain pihak penerima gala (urueng teurimong gala) menyerahkan uang atau emas yang akan dipinjamkan oleh pihak pemberi gala (urueng peugala) maka setelah adanya kesepakatan tersebut barulah para pihak memulai akad mudharabah (bagi hasil) atas objek gala (barang agunan). Ketika para pihak memulai akad mudharabah haruslah adanya penetapan nisbah (bagi hasil) di mana penetapan terhadap jumlah (nisbah) bagi hasil haruslah disepakati oleh kedua belah pihak

Maka dengan adanya penerapan akad mudharabah di dalam suatu transaksi gala sebagaimana dijelaskan diatas dengan otomatis pihak penerima gala (urueng teurimong gala) dibolehkan untuk memanfaatkan objek gala (agunan) yang dititipkan sebagai benda jaminan oleh pemberi gala (urueng peugala) kepada pihak penerima gala (urueng teurimong gala). 
Skema Mekanisme Pembiayaan dengan Konsep Mudharabah.

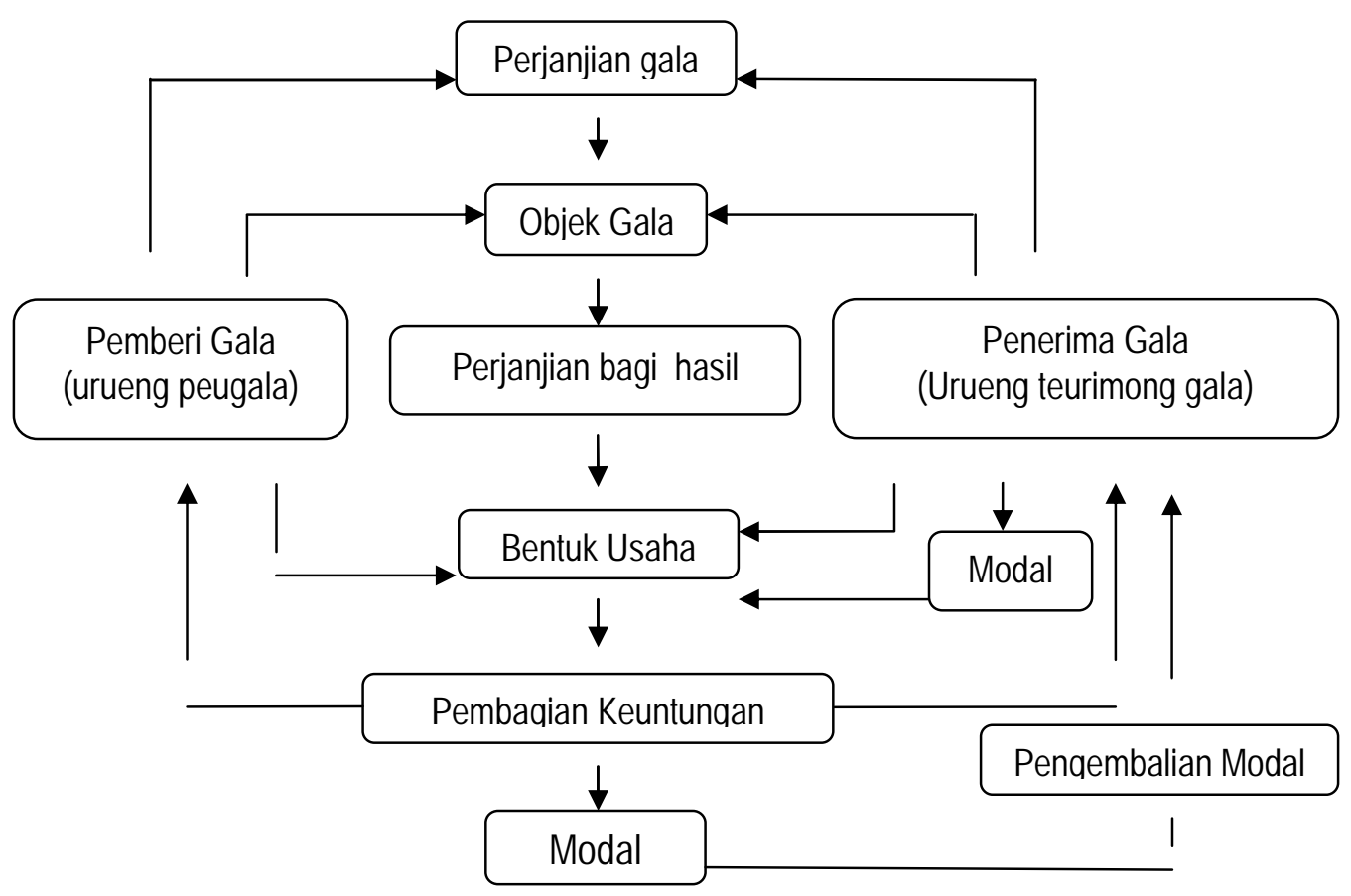

Apabila melihat skema di atas jika dalam perjanjian gala menerapkan akad mudharabah tentunya tidak akan menghilangkan nilai-nilai dan konsep tolong-menolong antar sesama, dan dengan adanya akad mudharabah keuntungan yang diperoleh dari objek gala (benda agunan) dapat dibagi dan dinikmati oleh kedua belah pihak sebagai mana diperjanjiakan sebelumnya, dan dilain sisi pihak pemberi gala (urueng peugala) juga akan merasakan akan sangat terbantu selain tidak memutuskan mata pendapatan (pencaharian) dengan adanya akad mudharabah dalam perjanjian gala juga akan menutupi hutang-hutang dari hasil pembagian keuntungan tersebut kepada pihak penerima gala (urueng teurimong gala).

\section{Simpulan Saran}

A. Simpulan

Maka berdasarkan pembahasan dan pemaparan pada bab-bab sebelumnya, maka penulis menyatakan beberapa kesimpulan sebagai berikut:

1. Perjanjian gala merupakan salah satu bentuk perjanjian pinjam-meminjam uang atau emas dengan menjadikan tanah atau barang-barang lainnya yang dianggap berharga sebagai objek jaminan (agunan). Perjanjian gala hanya dilakukan apabila pemberi gala (urueng peugala) membutuhkan uang yang besar dalam keadaan mendesak, dalam suatu 
mekanisme perjanjian gala apabila para pihak telah sepakat untuk melakukan perjanjian gala maka terjadilah serah terima (ijab kabul) yang diikuti dengan penyerahan tanahnya atau objek jaminan sebagai jaminan gala (barang agunan) dari pihak pemberi gala (urueng peugala) kepada pihak penerima gala (urueng trimong gala) dalam bentuk hak pakai, sedangkan dipihak penerima gala (urueng trimong gala) menyerahkan uang dengan kesepakatan yang dipenuhi sebagaimana telah diperjanjikan antara keduanya dalam bentuk tunai (cash). Berakhirnya suatu perjanjian gala dalam masyarakat adat Aceh adalah ketika objek gala (barang agunan) telah ditebus, Selama berlangsungnya perjanjian gala barang jamiman berada dalam penguasaan penerima gala (urueng teurimong gala) maka selama objek gala (barang agunan) belum ditebus oleh pihak pemberi gala (urueng peugala) maka pihak penerima gala (urueng teurimong gala) berhak untuk menikmati hasil dari objek gala (barang agunan) dikarenakan pemanfaatan atas objek gala merupakan suatu bentuk balas jasa dari pihak pemberi gala (urueng peugala) atas uang atau emas yang dipinjamkan oleh pihak penerima gala (ureung teurimong gala)
2. Gadai syariah (rahn) dalam masyarakat adat Aceh disebut dengan istilah perjanjian gala adalah suatu perbuatan berlandaskan nilainilai muammalah dalam bentuk suatu perjanjian pinjam-meminjam yang dapat dipersamakan dengan suatu perjanjian gadai di mana hak yang diperoleh kreditor (pemberi gadai) atas suatu barang bergerak, yang diserahkan kepadanya oleh debitur (penerima gadai) atau oleh seorang lain atas namanya dan yang memberikan kekuasaan kepada kreditor itu untuk mengambil pelunasan dari barang tersebut secara didahulukan dari pada kreditur-kreditur. Jika melihat praktik perjanjian gala yang berkembang pada masyarakat adat Aceh maka terdapat permasalahan mengenai penetapan batas waktu dan pemanfaatan atas barang gala (barang agunan). Sebagian besar para ulama tidak membolehkan pemanfatan barang galaan dengan tidak adanya suatu batasan waktu akan memberikan dampak adanya sutu ketidakjelasan dikarenakan dapat memberikan kemudharatan kepada pihak pemberi gala (urueng peugala) dan hasil dari pemanfaatan barang galaan dapat menjurus ke suatu perbuatan riba bagi pihak penerima gala (urueng peugala). Pemanfataan dan penguasaan pada objek 
gala atas dasar kemaslahatan dengan tujuan saling bantu-membantu antar sesama tentunya dibolehkan apabila pihak pemberi gala (urueng peugala) dan penerima gala (urueng teurimong gala) dalam pelaksanaan perjanjian gala sepakat untuk menerapkan 3 (tiga) akad perjanjian Perjanjian hutang piutang dengan gala dalam bentuk AlQardhul Hassan, Al-Mudharabah dan bentuk Bai' Al-Muqoyyadah.

3. Bentuk perjanjian gala yang berlaku di dalam masyarakat adat Aceh khususnya pada masyarakat Kemukiman Kuta reuntang tentunya adanya ketidak sesuaian antara pelaksanaan dengan isi ketentuan Pasal 2 ayat (2) Qanun Nomor 9 Tahun 2008 tentang Pembinaan kehidupan Adat dan Adat Istiadat yang menyebutkan bahwasanya: "Pembinaan, pengembangan, pelestarian, dan perlindungan terhadap adat dan adat istiadat dalam masyarakat adat Aceh harus berpedoman pada nilai-nilai Islami" dan Pasal 7 ayat (1) Undang-Undang Nomor 56 PRP Tahun 1960 tentang Penetapan Luas Tanah Pertanian yang mengatur batas waktu suatu perjanjian yang menjadikan tanah sebagai suatu objek gadai (agunan) tidak boleh lebih dari 7 (tujuh) tahun. Maka untuk menyesuaikan kembali perjanjian gala pada masyarakat
Kemukiman Kuta Reuntang maka perlunya adanya penetapan akad mudharabah dalam pelaksanaan perjanjian gala, dengan harapan dengan adanya penerapan suatu akad mudharabah akan menghilangkan unsur pemerasan (penindasan) antar sesama di mana dahulunya hasil pemanfaatan dari objek gala di anggap suatu bentuk balas jasa dari pihak pemberi gala (urueng peugala) kepada pihak penerima gala (urueng teurimong gala) maka dan dengan adanya penerapan konsep mudharabah hasil keuntungan yang diperoleh dari objek galaan oleh penerima gala (urueng teurimong gala) dapat menutup kembali utang pihak pemberi gala (urueng peugala).

\section{B. Rekomendasi}

Penelitian ini menawarkan suatu bentuk rekomendasi agar para pihak yang terlibat di dalam suatu perjajian gala agar dapat memanfaat objek gala (barang agunan) dengan menerapkan pelaksanaan akad mudharabah akad ijarah di mana keuntungannya akan diperoleh oleh kedua belah pihak dan hasil dari keuntungan juga akan menutupi utang dari pihak pemberi gala (urueng peugala) kepada pihak penerima gala (urueng teurimong gala) sesuai dengan kaidah dan ketentuan-ketentuan syariah sehingga nantinya dalam pelaksanaan 
perjanjian gala di Aceh nantinya dapat terhindar dari unsur-unsur penindasan dan riba.

Maka dari itu, diharapkan agar Pemerintah Aceh untuk membuat qanun khusus tentang tata cara tatacara pelaksanaan gala yang sesuai dengan ketentuan Islam yang berbasiskan syariah.

\section{Daftar Pustaka}

\section{Buku, Hasil Penelitian, J urnal dan Artikel}

A. Ghofur Anshori, 2006, Gadai Syariah di Indonesia, Yogyakarta: Gadjah Mada University Press

A. Malik, 1997, Perjanjian "Gala" dalam Masyarakat Hukum Adat Aceh di Kecamatan Lhoknga/Leupung Kabupaten DATI II Aceh Besar, Tesis, Medan: Program Pasca Sarjana Universitas Sumatera Utara.

Abdurrahman bin Nashir As-Sa'di, Tahqiq Asyraf Abdulmaqshud, 1992, Bahjah Qulub AlAbrar wa Qurratu Uyuuni Al-Akhyaar Fi Syarhi J awaami Al-Akhbaar, Cet. II, Dar AlJail.

Azharsyah Ibrahim, 2012, Praktik Ekonomi Masyarakat Aceh dalam Konteks Ekonomi Islam, Procceeding of the Aceh development International Conference, Malaysia: International Islamic University.
Brian Z. Tamanaha,2006, A General J urisprudence of Law and Society, New York: Oxford University Press

Esmi Warassih, "Urgensi Memahami Hukum dengan Pendekatan Socio-Legal dan Peranannya dalam Penelitian". Makalah Seminar Nasional Penelitian dalam Perspektif Socio-Legal dan, Bagian Hukum dan Masyarakat Fakultas Hukum Undip, Semarang, 22 Desember 2008.

Husen Alting, 2010, Dinamika Hukum dalam Pengakuan dan Perlindungan Hak Masyarakat Hukum Adat Atas Tanah, Yogyakarta: LaksBang PRESSindo.

Ifan Noor Adham, 2009, Perbandingan Hukum Gadai di Indonesia, Jakarta: Tatanusa.

Iman Sudiyat, 2010, Asas- Asas Hukum Adat Bekal Pengantar Cetakan ke.-5, Yogyakarta: Liberty.

Muhammad dan Sholikhul hadi, 2003, Pengadaian Syariah: Suatu Alternatif Konstruksi Pengadaian Nasional, Edisi 1, Jakarta: Salemba Diniyah

Muhammad, 2001, Tehnik Perhitungan Bagi Hasil di Bank Syariah, Yogyakarta: UII Press.

Purbayu Budi Santosa, Larangan J ual Beli Gharar: Tela'ah Terhadap Hadis dari Musnad 
Ahmad Bin Hanbal, Universitas T. Juned, Mustafa Ahmad dan Hakim Nyak Pha, Diponegoro, Vol. 3, No. 1, Juni 2015 2003, Bunga Rampai Menuju Revitalisasi Hukom dan Adat Aceh, Banda Aceh:

Reza Banakar and Max Travers, "law Sociology and Method", in Social and Legal Studies, International Institute, 2003.

Yayasan Rumpun Bambu

Taqwaddin Husen, 2013, Kapita Selekta Hukum Adat Aceh dan Qanun Wali Nanggroe, Banda Aceh: Bandar Publishing.

Studi Hukum, Malang: Bayumedia Publishing.

Ter Haar, B, 1979, Asas-asas dan Susunan Hukum , 2009, Pendidikan Hukum sebagai Pendidikan Manusia: kaitannya dengan profesi Hukum dan Pembangunan Hukum Nasional, Yogyakarta: Genta Publishing.

Sayuti Thalib, 1982, Receptio A Contrario, Cet. III, Jakarta: Bina Aksara. Adat (Terj. Soebakti Poesponoto), Jakarta: Pradnya Paramita.

Tolib Setiady, 2008, Intisari Hukum Adat Indonesia dalam Kajian Kepustakaan), Bandung: Alfabeta.

Zainuddin Ali, 2008, Hukum Gadai Syariah, Jakarta: Sinar Grafika.

Soetandyo Wignjosoebroto, 2012, Hukum: Paradigma.Metode dan Dinamika Masalahnya, Jakarta: HuMA

Zaki Fuad Chalil, 2008, Horizon Ekonomi Syariah: Pemenuhan Kebutuhan dan Distribusi Pendapatan, Banda Aceh: Ar-Raniry Press.

Sulaiman, 2010, Model Alternatif Pengelolaan Perikanan Berbasis Hukum Adat Laot di Kabupaten Aceh Jaya Menuju Keberlanjutan Lingkungan Yang Berorientasi Kesejahteraan Masyarakat, Tesis, Semarang: Universitas Diponegoro.

Suriyaman Mustari Pide A, 2014, Hukum Adat Dahulu, Kini dan Akan Datang, Jakarta: Penerbit Kencana Prenadamedia Group.

\section{PERATURAN PERUNDANG-UNDANGAN}

Undang-undang Dasar Negara Republik Indonesia Tahun 1945.

Kitab Undang-Undang Hukum Perdata.

Undang-Undang Nomor 18 Tahun 2001 tentang Otonomi Khusus untuk Aceh dengan Nama Provinsi Nanggroe Aceh Darussalam.

Undang-Undang Nomor 22 Tahun 1999 tentang Pemerintahan di Daerah. 
Undang-Undang Nomor 32 Tahun 2004 tentang Pemerintahan Daerah.

Undang-Undang Nomor 44 Tahun 1999 tentang Penyelenggaraan Keistimewaan Aceh.

Undang-Undang Nomor 7 Tahun 2007 tentang Pembentukan Kabupaten Pidie Jaya di Nanggroe Aceh Darussalam.

Undang-Undang Nomor 11 Tahun 2006 tentang Pemerintahan Aceh.

Undang-Undang Nomor 56/Prp/Tahun 1960 tentang Penetapan Luas Tanah Pertanian.

Peraturan Daerah Nomor 7 Tahun 2000 tentang penyelenggaraan kehidupan adat.

Qanun Aceh Nomor 4 Tahun 2003 tentang Pemerintahan Mukim.

Qanun Aceh Nomor 5 Tahun 2003 tentang Pemerintahan Gampong dan Propinsi Nanggroe Aceh Darussalam.

Qanun Aceh Nomor 9 Tahun 2008 tentang Pembinaan Kehidupan Adat dan AdatIstiadat.

Qanun Aceh Nomor 10 Tahun 2008 tentang Lembaga Adat.

Qanun Aceh Nomor 8 Tahun 2009 tentang Adat dan Istiadat. 